\title{
VARIATIONS IN SERUM FSH, LH AND TESTOSTERONE LEVELS IN MALE RATS FROM BIRTH TO SEXUAL MATURITY
}

\author{
V. W. K. LEE, D. M. DE KRETSER, B. HUDSON AND G. WANG \\ Monash University Department of Medicine and Medical Research Centre, \\ Prince Henry's Hospital, and Howard Florey Institute of Experimental \\ Physiology and Medicine, University of Melbourne, Australia
}

(Received 29th May 1974)

\begin{abstract}
Summary. Serum LH, FSH and testosterone concentrations were measured by radioimmunoassays in male Sprague-Dawley rats from birth to 80 days of age. The levels of FSH were significantly elevated during the first 5 days of postnatal life. An abrupt decline in FSH concentrations occurred during this period, from levels of $800 \mathrm{ng} / \mathrm{ml}$ on Day 1 to levels of $300 \mathrm{ng} / \mathrm{ml}$ on Day 6. Subsequently, FSH levels fluctuated widely until about Days 30 to 45 , when a secondary peak of FSH was observed. Thereafter, a decline in FSH levels to those found in adult rats occurred. This decline in FSH levels appears to coincide with the first release of mature spermatozoa from the germinal epithelium in the testis. During the first 30 days of postnatal life, $\mathrm{LH}$ and testosterone values appeared to be inversely related to each other and an LH peak and a nadir of testosterone levels was observed between Days 6 and 14 at a time corresponding to regression of the fetal generation of interstitial cells. A parallel rise in $\mathbf{L H}$ and testosterone levels occurred from Day 30 to sexual maturity and corresponded to the development of the adult generation of interstitial cells.
\end{abstract}

\section{INTRODUCTION}

The laboratory rat has been used extensively as an experimental animal for studies in reproductive physiology. Although several studies have attempted to evaluate pituitary-testicular interrelationships in this animal, the majority have been fragmentary and have not included the immediate postnatal period (Swerdloff, Walsh, Jacobs \& Odell, 1971; Goldman, Grazia, Kamberi \& Porter, 1971; Ojeda \& Ramirez, 1972; Miyachi, Nieschlag \& Lipsett, 1973; Negro-Vilar, Krulich \& McCann, 1973). None of these studies has extended from birth to sexual maturity and little effort has been made to correlate testicular histology and the hormonal fluctuations. The interval between birth and sexual maturity in the rat is approximately 50 days, and the failure to study the entire prepubertal period could lead to the omission of important data. Events in the immediate perinatal period in the rat could be important 
in the initiation of spermatogenesis since this process has been shown to take 48 days in this species (Clermont, 1972). In this study, the levels of FSH, LH and testosterone in the blood of rats from birth to sexual maturity has been determined, and the histology of the testis in these animals has been correlated with changes in the hormonal levels.

\section{MATERIALS AND METHODS}

\section{Animals}

The animals used were male Sprague-Dawley rats which were bred at Prince Henry's Hospital, Melbourne. Rats of known age were decapitated and blood samples were collected, allowed to clot, and the sera were stored at $-20^{\circ} \mathrm{C}$ until assay. In general, blood samples obtained from rats less than 30 days of age were pooled from up to fourteen animals to obtain sufficient quantities of serum for assay.

\section{Assays}

Serum LH and FSH were measured by double antibody systems using reagents supplied by the Rat Pituitary Hormone Distribution Program, NIAMD. Both purified rat LH (NIAMD-rat-LH-I-1) and rat FSH (NIAMD-rat-FSH-I-1) were iodinated with ${ }^{125} \mathrm{I}$ by the chloramine-T method (Greenwood, Hunter \& Glover, 1963) and the labelled hormones were purified by gel filtration using Bio-gel $\mathrm{P} 60$ columns $(1 \times 10 \mathrm{~cm})$ previously equilibrated with $0.05 \mathrm{M}$-phosphate buffer, $\mathrm{pH} 7.5$, and pre-treated with egg albumin. The values for LH were expressed in terms of NIAMD-rat-LH-I-1 and FSH concentrations were given in terms of NIAMD-rat-FSH-RP-1. The potency of the unknown serum samples and the coefficient of variation of the assays were calculated with the aid of a computer programme (Burger, Lee \& Rennie, 1972). The sensitivity in $n g$ (mean \pm S.D.) of nine assays for the $L H$ assay was $0 \cdot 11 \pm 0.06$ and for the FSH assay was $1.04 \pm 0.26$. Within-assay precision of the $\mathbf{L H}$ and $\mathrm{FSH}$ systems ranged from 3.2 to $8.7 \%$ at the most sensitive part of the curves. Cross-reaction in the LH radioimmunoassay by rat FSH was less than $3 \%$ and in the FSH radioimmunoassay by rat LH was less than $6 \%$.

Serum testosterone was measured by radioimmunoassay (Wang, Youatt, O'Connor, Dulmanis \& Hudson, 1973) without using a chromatographic step with an antiserum raised specifically against testosterone-3-carboxymethyloxime coupled to thyroglobulin. The minimal amount of testosterone per sample which could be measured with good reliability was $50 \mathrm{pg}$, and the intraassay precision was $\pm 10.8 \%$ coefficient of variation. In order to avoid interassay variation, all samples collected were measured within a single assay.

\section{RESULTS}

\section{Analysis of results}

In order to cope with the wide variations obtained in the levels of FSH, LH and testosterone, the results were arbitrarily grouped into 5-day intervals for animals less than 30 days of age and into 10-day intervals for animals between 
Table 1. Serum LH, FSH and testosterone levels ( $\mathrm{ng} / \mathrm{ml}$ serum) in male rats from birth to 80 days of age

\begin{tabular}{|c|c|c|c|}
\hline $\begin{array}{c}\text { Age of rats } \\
\text { (days) }\end{array}$ & $F S H$ & $L H$ & Testosterone \\
\hline $\begin{array}{l}0 \text { to } 5 \\
6 \text { to } 10 \\
11 \text { to } 15 \\
16 \text { to } 20 \\
21 \text { to } 25 \\
26 \text { to } 30 \\
31 \text { to } 40 \\
41 \text { to } 50 \\
51 \text { to } 60 \\
61 \text { to } 70 \\
71 \text { to } 80\end{array}$ & $\begin{array}{l}660 \pm 58(14) \\
285 \pm 33(6) \\
282 \pm 22(5) \\
215 \pm 37(11) \\
262 \pm 53(8) \\
421 \pm 15(2) \\
288 \pm 32(5) \\
366 \pm 75(4) \\
193 \pm 20(4) \\
219 \pm 55(5) \\
230 \pm 37(3)\end{array}$ & $\begin{array}{l}3.37 \pm 0.5(14) \\
4.52 \pm 0.2(6) \\
3.86 \pm 0.6(5) \\
2.79 \pm 0.3(11) \\
3.51 \pm 0.3(8) \\
0.61 \pm 0.01(2) \\
1.92 \pm 0.3(5) \\
2 \cdot 69 \pm 0.6(4) \\
3.24 \pm 0.6(4) \\
5.07 \pm 0.2(5) \\
3.86 \pm 0.3(3)\end{array}$ & $\begin{array}{l}0.76 \pm 0.16(6) \\
0.55 \pm 0.10(5) \\
0.63 \pm 0.17(7) \\
0.87 \pm 0.21(4) \\
0.37 \pm 0.07(3) \\
0.95 \pm 0.30(5) \\
0.78 \pm 0.21(4) \\
0.94 \pm 0.19(4) \\
1.10 \pm 0.28(2) \\
1.82 \pm 0.32(3) \\
2.15 \pm 0.32(5)\end{array}$ \\
\hline
\end{tabular}

Values are given as Mean \pm S.E.M. $(n)$ where $n=$ no. of serum samples. Each serum sample represents a serum pool from two to fourteen animals.

30 and 80 days of age; the mean and standard error were calculated for each 'age' interval represented (Table 1 and Text-figs 1,2 and 3).

\section{Serum FSH levels}

Serum FSH levels were significantly elevated during the first 5 days of life with values from 366 to $941 \mathrm{ng} / \mathrm{ml}$ (Text-fig. 1; Table 1). An abrupt decline in FSH concentrations occurred shortly after reaching levels of 200 to $300 \mathrm{ng} / \mathrm{ml}$

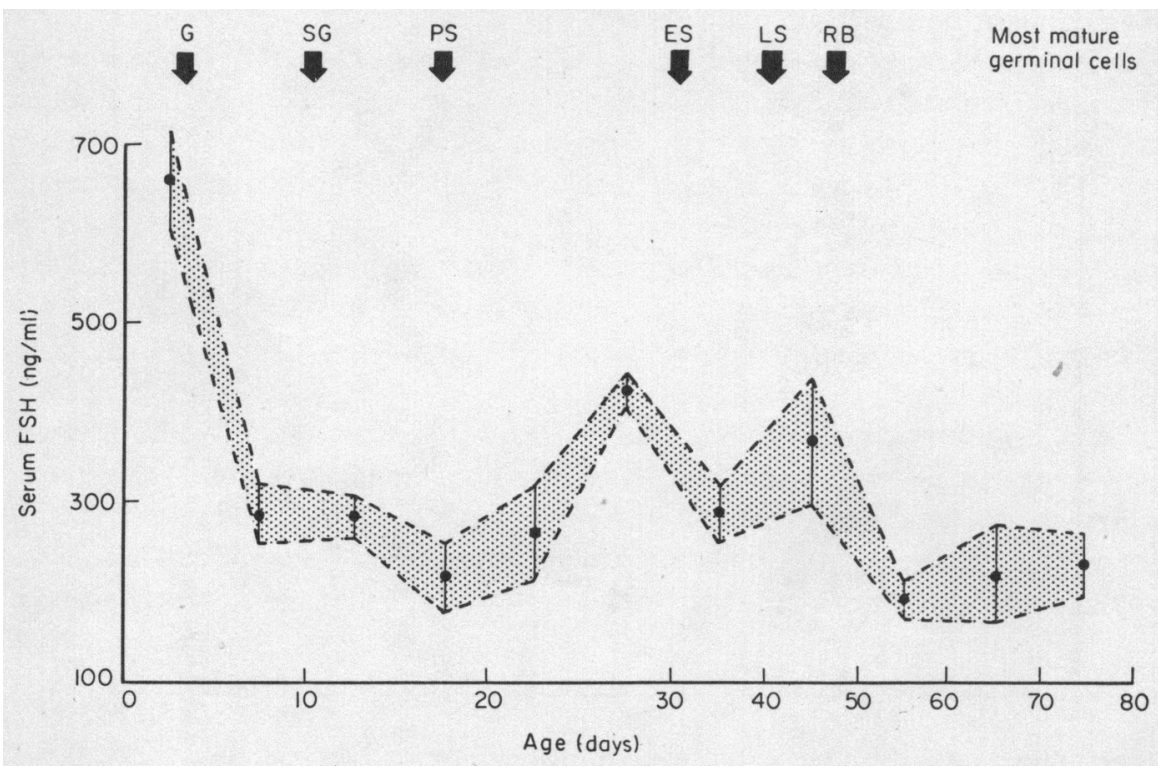

TExT-Fig. 1. A profile of FSH levels during the development of the male rat. For the number of rats represented by each point, see Table 1 . The times at which different germinal cells appear in the testis are represented: $\mathbf{G}=$ gonocytes; $\mathrm{SG}=$ spermatogonia; PS = primary spermatocytes; $\mathrm{ES}=$ early spermatids; LS = late spermatids; $\mathbf{R B}=$ residual bodies. Vertical bars represent the Mean \pm S.E.M. 


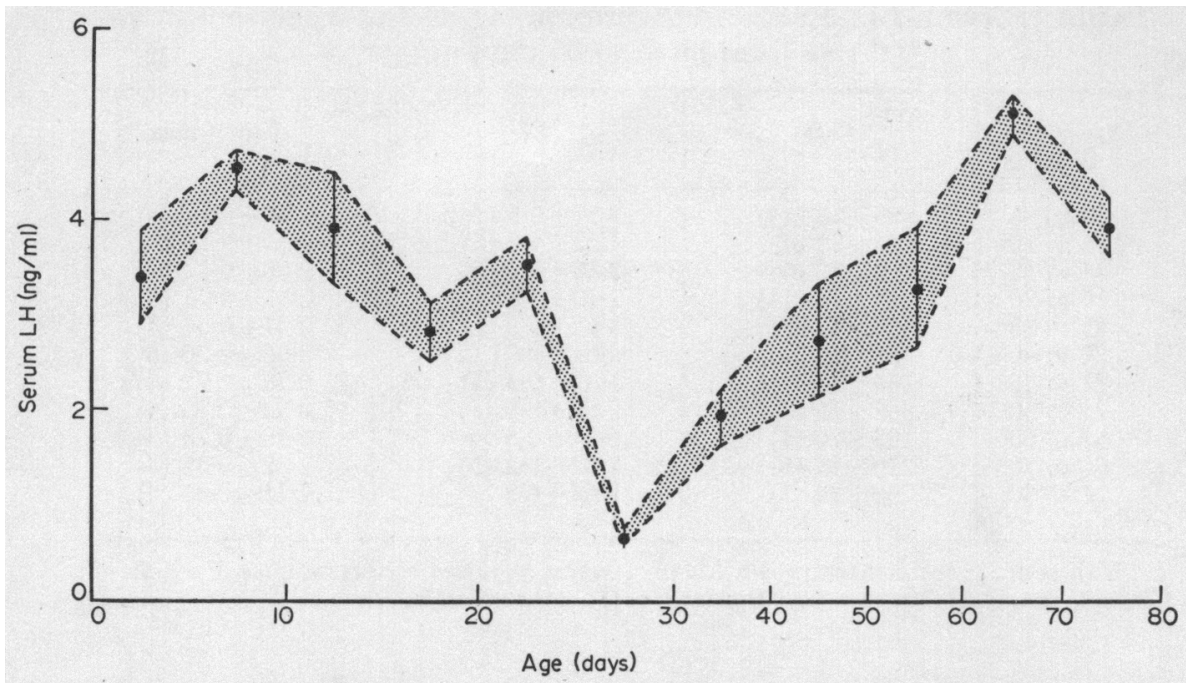

TEXT-Fig. 2. A profile of LH levels during the development of the male rat. For the number of rats represented by each point, see Table 1 . Vertical bars represent the Mean \pm S.E.M.

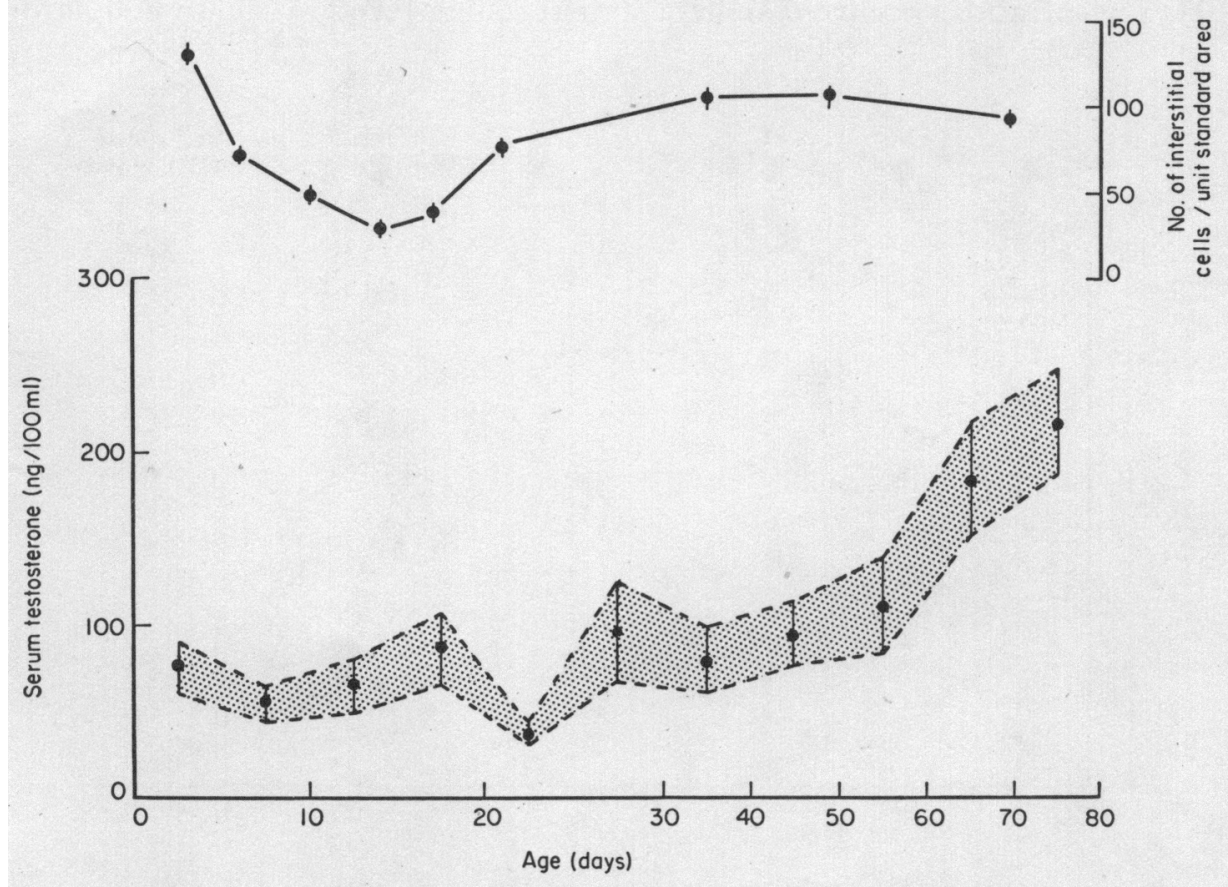

Text-Fig. 3. A profile of testosterone levels during the development of the male rat. For the number of rats represented by each point, see Table 1 . The top panel represents the number of mature interstitial cells per unit standard area of testicular biopsy (Lording $\&$ de Kretser, 1972). Vertical bars represent the Mean \pm S.E.M. 
between Days 6 and 10. Thereafter, marked variability of the FSH levels was noted from Days 10 to 30 with levels distributed over a range of 60 to $400 \mathrm{ng} / \mathrm{ml}$. Between 30 and 45 days of age, the FSH levels rose to levels in excess of 250 $\mathrm{ng} / \mathrm{ml}$ and subsequently declined slightly to those found in adult rats (100 to $300 \mathrm{ng} / \mathrm{ml}$ ). The principal correlation between serum FSH levels and germinal cell development was the decrease in FSH levels found after Day 50, the time at which spermatozoa are released from the seminiferous epithelium.

\section{Serum $L H$ and testosterone levels}

The LH and testosterone levels at different stages of development are illustrated in Text-figs 2 and 3 and Table 1 . Serum LH levels ranged between 1 and 6 $\mathrm{ng} / \mathrm{ml}$ from birth to 25 days and declined to reach a nadir between 25 and 30 days. Subsequently, a gradual rise was evident and peak levels were reached between 60 and 70 days.

The serum testosteronelevels were usually below $100 \mathrm{ng} / 100 \mathrm{ml}$ from birth to 50 days. A stepwise rise then occurred to reach levels in excess of $230 \mathrm{ng} / 100 \mathrm{ml}$ between Days 70 and 80. Before Day 25, fluctuations in the levels of testosterone occurred and, in general, these were associated with reciprocal changes in the LH levels.

\section{DISCUSSION}

In view of the fact that the spermatogenic process in the rat commences within a few days after birth, it is of interest to note that serum FSH levels were markedly elevated during the 1st week of life. Similar levels were found by Miyachi et al. (1973) even though their studies commenced on Day 5. The elevated levels of FSH may be involved in the initiation of the spermatogenic process involving division of gonocytes to form spermatogonia (Glermont \& Perey, 1967). Alternatively, these high levels may reflect a functional immaturity of the hypothalamo-hypophysial unit. This suggestion is supported by observations that the vascular hypothalamo-pituitary connection develops only after the 5th postnatal day (Glydon, 1957; Fink \& Smith, 1971), and that catecholamine fluorescence in the median eminence of the hypothalamus does not intensify until Day 5 (Smith \& Simpson, 1970).

The secondary peak of serum FSH levels seen between the 4th and 7th postnatal week has been identified in several other studies (Swerdloff et al., 1971; Miyachi et al., 1973; Negro-Vilar et al., 1973). The elevated levels during this period may be associated with the maturation of spermatids and the subsequent decline suggests that an intact and mature seminiferous epithelium is required to exert a feedback influence on FSH secretion. It is of interest that the initiation of this rise occurs in concert with rising LH levels which continue to rise after FSH levels have declined and this dissociation strongly suggests independent control systems for these two hormones.

The patterns of LH and testosterone levels in the blood of rats from birth to 20 days of age are reciprocally related. Testosterone levels present at birth are presumably secreted by the fetal generation of interstitial cells which virtually disappear by the second week of postnatal life (Lording \& de Kretser, 
1972) and this decline in the number of interstitial cells is accompanied by a nadir of serum testosterone levels. The peak of serum LH seen at this time provides suggestive evidence of a functional pituitary-testicular relationship and may serve to initiate development of the adult generation of interstitial cells. Fluctuations of $\mathrm{LH}$ and testosterone levels during the 2nd and 3rd postnatal week in Holtzman male rats have been noted by Miyachi et al. (1973) although their significance remains unknown. The parallel rise in the levels of serum $\mathrm{LH}$ and testosterone seen between Days 25 and 65 is suggestive evidence that a higher level of testosterone is required to exert feedback on LH secretion.

\section{ACKNOWLEDGMENTS}

This work was supported by the National Health and Medical Research Council of Australia. We thank Mrs C. Bristow for help with the illustrations and Mrs J. Volfsbergs for typing the manuscript.

\section{REFERENGES}

Burger, H. G., Lee, V. W. K. \& Rennie, G. G. (1972) A generalized computer program for the treatment of data from competitive protein-binding assays including radioimmunoassays. $\mathcal{F}$. Lab. clin. Med. 80, 302-312.

Clermont, Y. (1972) Kinetics of spermatogenesis in mammals: seminiferous epithelium cycle and spermatogonial renewal. Physiol. Rev. 52, 198-236.

Clermont, Y. \& Perey, B. (1957) Quantitative study of the cell population of the seminiferous tubules in immature rats. Am. 7. Anat. 100, 241-268.

Fink, G. \& Sмrтh, G. G. (1971) Ultrastructural features of the developing hypothalamo-hypophyseal axis in the rat. A correlative study. Z. Zellforsch. mikrosk. Anat. 119, 208-226.

Glydon, R. S. (1957) The development of the blood supply of the pituitary in the albino rat, with special reference to the portal vessels. 7. Anat. 91, 237-244.

Goldman, B. D., Grazia, Y. R., Kamberi, I. A. \& Porter, J. G. (1971) Serum gonadotrophin concentrations in intact and castrated neonatal rats. Endocrinology, 88, 771-776.

Greenwood, F. G., Hunter, W. M. \& Glover, J. S. (1963) The preparation of ${ }^{131}$ I-labelled human growth hormone of high specific radioactivity. Biochem. 7. 89, 114-123.

Lording, D. W. \& DE KRETSER, D. M. (1972) Comparative ultrastructural and histochemical studies of the interstitial cells of the rat testis during fetal and post-natal development. $\mathcal{F}$. Reprod. Fert. 29, 261-269.

Mryachi, Y., Nieschlag, E. \& Lipsett, M. B. (1973) The secretion of gonadotrophins and testosterone by the neonatal male rat. Endocrinology, 92, 1-5.

Negro-Vilar, A., Krulich, L. \& McGanN, S. M. (1973) Ghanges in serum prolactin and gonadotropins during sexual development of the male rat. Endocrinology, 93, 660-664.

OJeda, S. R. \& Ramirez, V. D. (1972) Plasma level of LH and FSH in maturing rats: response to hemigonadectomy. Endocrinology, 90, 466-472.

Smith, G. G. \& Simpson, R. W. (1970) Monoamine fluorescence in the median eminence of foetal, neonatal and adult rats. Z. Zellforsch. mikrosk. Anat. 104, 541-556.

Swerdlofr, R. S., Walsh, P. G., Jacobs, H. S. \& Odell, W. D. (1971) Serum LH and FSH during sexual maturation in the male rat: effect of castration and cryptorchidism. Endocrinology, 88, 120-128.

Wang, G., Youatt, G., O'Gonnor, S., Dulmanis, A. \& Hudson, B. (1973) A simple radioimmunoassay for plasma testosterone. Programme, 16th Annual Meeting, The Endocrine Society of Australia, Adelaide, Abstr. No. 19. 